\title{
James Cook's 1769 transit of Venus expedition to Tahiti
}

\author{
Wayne Orchiston \\ Anglo-Australian Observatory \& Australia Telescope National Facility, \\ PO Box 296, Epping, NSW 2121, Australia \\ wo@aaoeapp.aao.gov.au
}

\begin{abstract}
After the failure of the 1761 transit to provide a reliable value for the astronomical unit, the focus shifted to the 1769 event, and Britain mounted an ambitious program, with overseas observing parties dispatched to North Cape (Norway), Hudson Bay (Canada) and newly-discovered Tahiti in the Pacific. Lieutenant James Cook was in charge of the Tahitian expedition, ably assisted by fellow-astronomer, Charles Green, and they were supplied by the Royal Society and the Royal Observatory at Greenwich with telescopes and other scientific instruments. The main observing site was set up at Fort Venus, and supplementary transit stations were established on Irioa Island (Moorea) and Taaupiri Island (off the east coast of Tahiti). June 3 was warm and clear, and all observers successfully recorded the transit, but on the journey home 'the curse of the transit' prevailed and more than half of them fell ill and died. Back in England, Cook wrote up the transit observations for the Philosophical Transactions of the Royal Society, but for some inexplicable reason only used data obtained at Fort Venus. It was left to Oxford astronomer, Professor Thomas Hornsby, to derive a meaningful figure for the solar parallax, and he utilized the Tahitian data and observations made at four other sites to arrive at a figure of $8 . ' 78$. But discordant results obtained by other researchers fuelled controversy over the effectiveness of transits of Venus as a valid means of determining the astronomical unit. In fact, the solar parallax obtained by Hornsby was remarkably similar to the currently-accepted value of 8 .'794148, thereby discrediting Beaglehole's oft-quoted claim that the Tahitian observations were a failure. Although more than a dozen men were involved in the Tahitian transit program, most of their records have been lost, and remarkably few of the instruments they employed can now be identified. Yet for those of us with Pacific affiliations, Cook's first voyage to the South Seas occupies a special place in transit of Venus history.
\end{abstract}

\section{Introduction}

During the eighteenth and nineteenth centuries transits of Venus were viewed as ideal tools with which to attack that fundamental yardstick of solar system astronomy: the value of the solar parallax $(\mathrm{P})$ and hence the astronomical unit. Although the transit of 1761 marked the first great scientific project undertaken on an international scale (Woolf 1959), results were inconclusive, with values of $\mathrm{P}$ ranging from 8 "' 28 to 10 "' 6 . Understandably, the focus then shifted to the up-coming 1769 transit.

\section{The preparations}

During the 1761 transit, Britain and Prussia were at war with Austria, France, Russia, Saxony and Sweden, but by 1769 the Seven Years' War was a distant memory. So, what better was of 'competing for peace' than through scientific supremacy? Thomas Hornsby, Professor of Astronomy at Oxford University, alluded to this when he wrote: "It behoves us therefore to profit as much as possible by the favourable situation of Venus in 1769, when we may be assured the several Powers of Europe will again contend which of 
them shall be most instrumental in contributing to the solution of this grand problem." (Hornsby 1765: 343). In Britain, a Transit of Venus Committee was formed by the Royal Society in 1767, featuring (amongst others) the Astronomer Royal, Nevil Maskelyne, and Dr John Bevis, James Ferguson and James Short, all leading British astronomers of the day. After referring to Hornsby's paper (1765: 339), they reviewed possible overseas observing sites, settling on North Cape (Norway), Hudson Bay (Canada) and a suitable Pacific site. Fortuitously, Samuel Wallis returned from a voyage of exploration in May 1768 and announced the discovery of King George's Island - now known as Tahiti - at precisely the desired Pacific location! Moreover, the climate was admirable, the locals were friendly, and there was a suitable harbour at Port Royal (Matavai Bay).

The Transit of Venus Committee adopted all three localities, and successfully petitioned King George III for $£ 4,000$ to finance the Pacific expedition (see Banks n.d.: 512513). They also requested a suitable vessel, and the Admiralty spent $£ 2,307.5$ s.6d purchasing the Earl of Pembroke (Deptford Yard Officers 1768a), and a further $£ 2,293.17 \mathrm{~s} .7 \mathrm{~d}$ modifying it for the voyage (Deptford Yard Officers 1768b). Renamed Endeavour, this 370 ton ex-Whitby collier proved cramped quarters for nigh on 100 men, comprising officers, marines and able-bodied seamen from the Royal Navy, and non-naval personnel referred to collectively as 'supernumeraries'. Most of the latter were members of Banks' scientific retinue, but a notable exception was one of the two official astronomers on the voyage, Charles Green.

Green (see Orchiston 1998b: 19-20) was eminently qualified for the task at hand, as he had participated in the Royal Observatory's 1761 transit of Venus programme. Born in Yorkshire in 1734, he served as a teacher before finding employment at the Observatory, but when Maskelyne became Astronomer Royal in 1765 and eventually appointed his own assistant, Green found himself without a job. His solution was to serve as purser on R.N. Aurora, before accepting the Endeavour appointment. Beaglehole (1968: ccxlii) has characterized Green as "... a highly conscientious as well as sprightly person."

The second astronomer on the Endeavour was none other than James Cook, who had dual responsibilities - and salaries - as commander of the vessel and astronomer (e.g. see Beaglehole 1968: cv; cxxvi, Banks n.d.: 513-514). Badger (1970: 30) claims that we are fully justified in regarding Cook as a 'scientist', in that he "... was a scrupulously careful observer ... [and] His attitude to measurement and inquiry would do credit to any conventionally-trained scientist." Six years Green's senior, Cook also was born in Yorkshire, and while still a teenager found service on North Sea coastal colliers. Eager to learn and improve, his training in seamanship received a distinct fillip in 1755 when he joined the Royal Navy as an able bodied seaman, and from 1757 to 1767 he learnt and practiced the principles of maritime astronomy, hydrographic surveying and cartography whilst serving on the American coast (Ritchie 1978; Skelton 1954). During this period, he also observed the 5 August 1766 total solar eclipse, a short report on which (see Cook 1767) was published in one of the most prestigious scientific journals of the day, the Philosophical Transactions of the Royal Society (of London). So when the Admiralty was reviewing possible commanders for the Endeavour, Cook was already known for his prowess in maritime and non-maritime astronomy, even though there were other officers who far out-ranked him (Beaglehole 1974). At the time he held the rank of master and commanded a naval schooner, the Grenville, but on 25 May 1768 he received a letter from the Admiralty advising that "... we have appointed you first Lieutenant of His Majesty's Bark the Endeavour now in Deptford, and intend that you shall command her during her present intended Voyage ..." (Admiralty 1768).

The Royal Society, with assistance from Nevil Maskelyne, was eager to provide Cook and Green with the best possible astronomical instruments (Howse 1979; Howse \& 


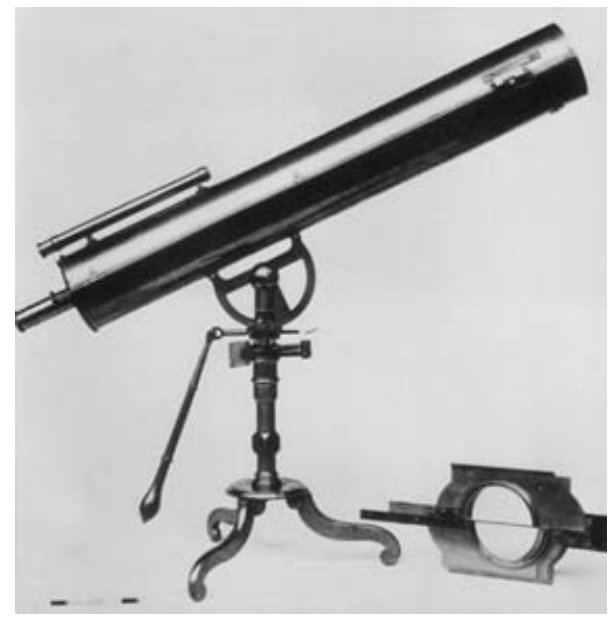

Figure 1. Gregorian reflector 1900-136, by Short, with object-glass micrometer (Courtesy: Science Museum, Science and Society Picture Library).

Hutchinson 1969; Orchiston 1998b: 36-58), namely: "2 Reflecting telescopes of two feet focus ... [with] 2 Wooden stands ... An astronomical quadrant of one foot radius, made by Mr Bird ... An astronomical Clock [by Shelton] and Alar[u]m Clock. A brass Hadley's sextant ... of Mr Ramsden. A Journeyman Clock bespoke of Mr Shelton. 2 Thermometers of Mr Bird. 1 Stand for Bird's quadrant." (Beaglehole 1968: cxliii). The two telescopes were Gregorian reflectors made by the celebrated Scottish instrument-maker, James Short (Green \& Cook 1771: 398), and one of these was furnished with a Dollond object-glass micrometer (see Fig. 1). The Navy Board also provided a Gregorian telescope that Cook had used previously on the Grenville, and before the departure of the Endeavour he had a micrometer made for it, convinced that this accessory "... will be of great service in the observation of the Transit Vinus $[$ sic $]$..." (Cook 1768). This telescope had a focal length of 18 inches (Green \& Cook 1771: 416), and we know from later Cook voyage documentation that it was made by Watkins (Beaglehole 1967, I: 243). In addition, Dr Daniel Solander, one of Banks' party, had access to a Gregorian telescope of 36 inches focal length (Green \& Cook 1771: 412). Apart from these four Gregorian reflectors there must have been others, but no documentation of these has survived. The only other scientific instrument of astronomical relevance was a watch, which Maskelyne loaned to Cook (Howse \& Hutchinson 1969). The clocks were there to provide a local time service during shore-based stopovers; the quadrant and sextant allowed observations vital in the determination of latitude and longitude, and maintaining a local time-service; and the telescopes were primarily supplied for the all-important observations of the transit.

\section{The voyage and the transit}

On 26 August 1768 the Endeavour sailed from Plymouth on an astronomical extravaganza (Betts 1993; Orchiston 2004), and one of the most expensive and ambitious expeditions ever undertaken by Mother England (Orchiston 1998a). To all intents and purposes this was a scientific voyage: at issue was the most pressing problem in world astronomy, and at stake was British pride and prestige.

After rounding Cape Horn, the Endeavour penetrated the Pacific, and on 13 April 1769 anchored in Matavai Bay on the northern coast of Tahiti more than seven weeks 


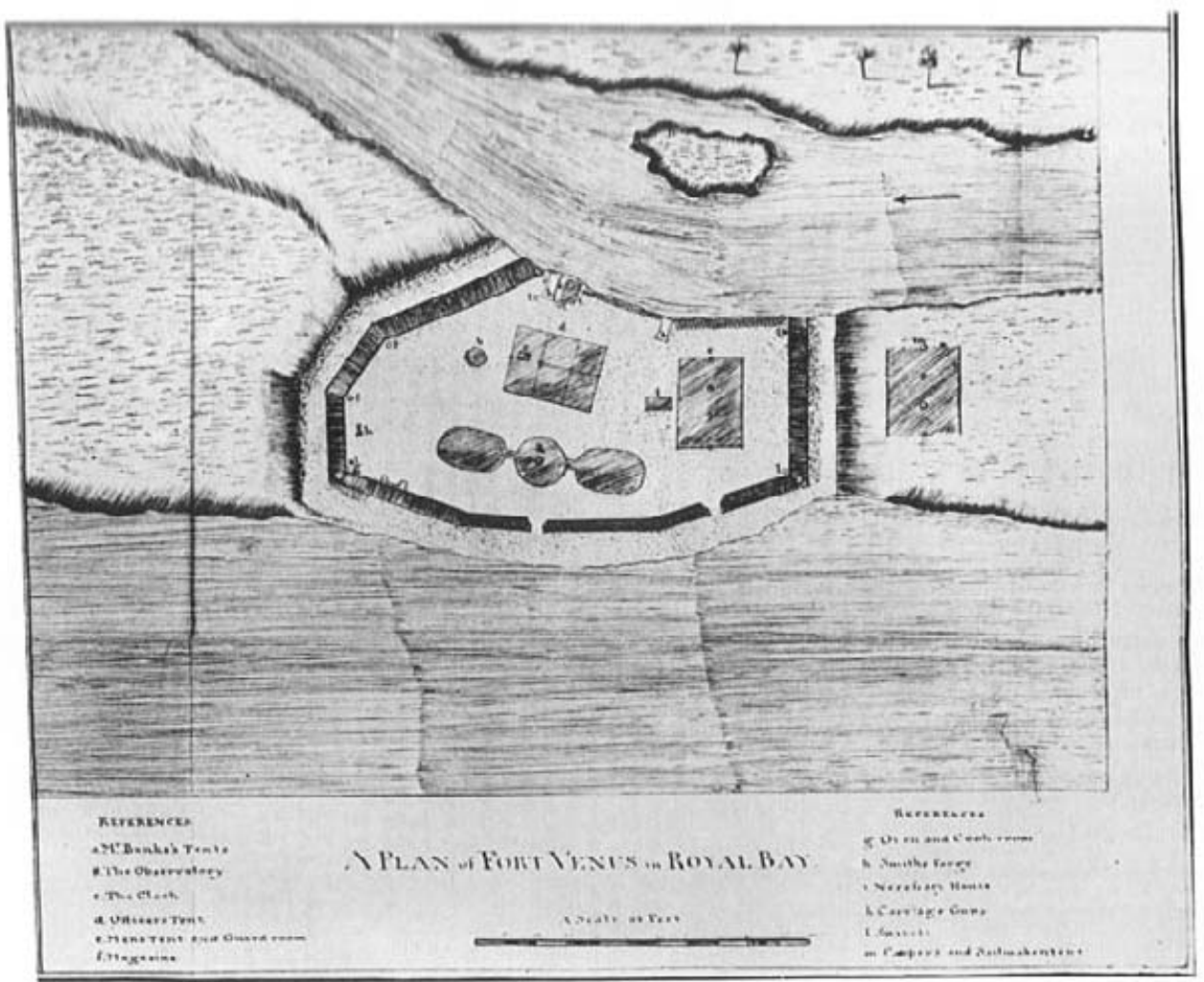

Figure 2. Plan of Fort Venus, Matavai Bay (after Parkinson 1784: Plate IV), showing the location of the circular tent observatory which housed the quadrant and journeyman clock, and the large rectangular tent with the astronomical clock.

before the scheduled transit. Nearby Point Venus proved an ideal observatory site: it was easily accessed from the ship, and lay on a narrow strip of land that could readily be fortified (for it was vital that there were no local interruptions during observation of the transit). Thus, Fort Venus came into existence, replete with an assortment of tents for men and instruments (Fig. 2). Green \& Cook (1771: 398) report that near one of the tents "... stood the observatory, in which were set up the journeyman clock and astronomical quadrant: this last, made by Mr. Bird, of one foot radius, stood upon the head of a large cask fixed firm in the ground ..." This quote reveals the way in which the quadrant and the telescopes were used: empty casks originally used to transport food or water were sunk into the sand and filled with sand for ballast. In this way they provided sturdy and reliable foundations for the delicate scientific instruments.

A key factor that would later influence the success of the entire expedition was accurate determination of the latitude and longitude of Fort Venus, and Green made this one of his priorities. To determine the latitude of the site he used quadrant observations of meridian zenith distances of the Sun obtained between May 6 and June 27 and meridian zenith distances of fifteen bright stars observed between June 21 and July 4, deriving a mean value of $17^{\circ} 29^{\prime} 15^{\prime \prime} \mathrm{S}$ (Green \& Cook 1771: 405-406). For longitude, he measured 'lunars' with the quadrant or Ramsden sextant on sixteen evenings between April 30 and June 30 , arriving at a figure $149^{\circ} 36^{\prime} 38^{\prime \prime} \mathrm{W}$ of Greenwich. In close accord was the value of $149^{\circ} 32^{\prime} 30^{\prime \prime} \mathrm{W}$, obtained by Green and Cook from telescopic observations of Jovian 


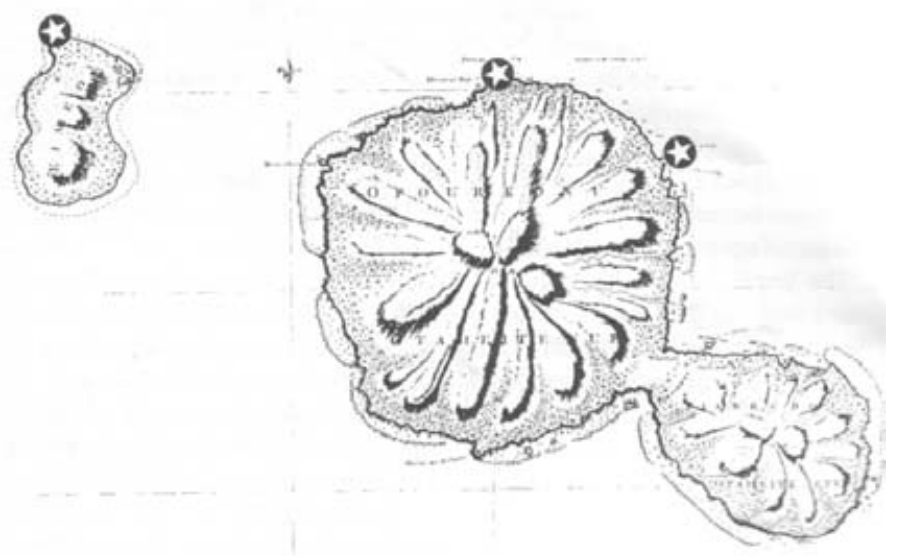

Figure 3. The stars indicate the locations of the three Tahitian transit of Venus observing sites. From west to east they are: Irioa Island, Fort Venus and Taaupiri Island.

satellite eclipses made on seven different nights between June 4 and July 6 (Green \& Cook 1771: 407-409).

As the date of the transit neared, Cook observed that the Fort Venus region was not always blessed with clear skies, so he decided to follow the advice proffered him before the voyage by the President of the Royal Society (see Douglas n.d.: 516) and establish two ancillary observing stations (see Fig. 3). One of these was sited on Irioa Island just off the north-western tip of adjacent Moorea, and comprised no more than "... a Coral rock about 150 yards from the shore ... it was about 80 yards long and 60 broad and had in the middle of it a bed of white sand large enough for our tents ..." (Beaglehole 1963, I: 284). The other supplementary observing station was on Taaupiri Island, an islet off the shore of Tahiti to the east-southeast of Fort Venus (see Beaglehole 1968: 97n). Fortunately there were enough instruments to accommodate three observing stations (Cook 1770), while Green had made sure that there would be suitable observers by providing lessons in nautical and transit astronomy during the voyage out from England (Beaglehole 1968: cxxxiv).

June 3, the day of the long-awaited event, loomed warm and clear throughout Tahiti, which boded well for the three teams of observers. At Fort Venus, Cook and Green used the two Short telescopes (Green \& Cook 1771: 398), while Solander carried out independent observations with a much larger, more powerful Gregorian reflector (Beaglehole 1968: 98). A Swede by birth and a disciple of Linneaus, Dr Daniel Solander (1733-1782) was Banks' botanical mainstay on the voyage (Beaglehole 1968: cxxxiv-cxxxvi). A fourth member of the Fort Venus team was Robert Molyneux (1747-1771), a Master on the Endeavour with a particular aptitude for marine surveying and cartography (see Beaglehole 1968: cxxxii). He, too, was furnished with a telescope (Molyneux 1769: 559), and although no description of this instrument has survived it was probably the Watkins reflector that had kept Cook company on American coast. We know that this Gregorian reflector was at Fort Venus during the transit, and that Cook made use of it between second and third contact (Green \& Cook 1771: 416). Perhaps Molyneux had recourse to it during the ingress and egress phases. As the principal observing station, it is reasonable to presume that the astronomical clock remained at Fort Venus for the transit (although this is nowhere stated in the literature). John Satterley, the Endeavour's ever-popular carpenter, was assigned responsibility for the clock and the thermometer (Molyneux 1769: 
559). He, Green and Molyneux were all destined to die in early 1771, while the Endeavour was en route to England, following the disastrous Batavia and Cape Town stop-overs.

The Taaupiri observing team was made up of Zachary Hicks, Charles Clerke, Richard Pickersgill and Patrick Saunders (ibid.). As Second Lieutenant on the Endeavour, Hicks (1739-1771) was Cook's second-in-command, while Third Lieutenant Clerke (1743-1779) ranked fourth in the hierarchy. Clerke had a special affinity for astronomy, and was to take over Green's responsibilities after the latter's untimely decease during the voyage home. Assisting Hicks and Clerke were Pickersgill (1747-1779), like Molyneux a Master with a talent for surveying and cartography, and Saunders, a little-known and quarrelsome Midshipman. Nowhere is there a listing of the specific instruments assigned to Taaupiri Island, but Molyneux (op. cit.) states that Green provided both ancillary transit parties “... with Telescopes \& every thing necessary ...". Precisely how many telescopes were supplied is not stated, but long after the transit Cook (1771a: 694) identified all four members of the transit party as observers. Local time, meanwhile, would have been provided by either the journeyman clock or the alarum clock.

The Irioa Island observing party also comprised four members: John Gore, Jonathan Monkhouse, William Brougham Monkhouse and Herman Spöring (Molyneux 1769: 559). American-born Third Lieutenant John Gore $(\sim 1730-1790)$ was an "... invaluable practical man ..." (Beaglehole 1968: 595) who ranked third in the officer's hierarchy, while Jonathan Monkhouse was a Midshipman, and his older brother, William Brougham Monkhouse, was the Endeavour's surgeon. Both Monkhouses were to die on the voyage home, William in November 1770 and Jonathan in February of the following year. The fourth member of the observing party was Swedish-born Spöring ( 1733-1771), who had trained in medicine and then worked as a watch-maker, but came on the voyage, with Banks, as an artist and draftsman. He also was to die on the way home. On the day of the transit Banks identified the two observers as Jonathan Monkhouse and Gore (Beaglehole 1963, 1: 284), whereas Cook says “... I sent Lieutenant Gore in the Long-boat to York Island [Moorea] with $\mathrm{D}^{\mathrm{r}}$ Monkhouse and $\mathrm{M}^{\mathrm{r}}$ Sporing to observe the transit of Venus, $\mathrm{M}^{\mathrm{r}}$ Green having furnished them with Instruments for that purpose." (Beaglehole 1968: 97). To confuse matters further, long after the transit Cook (1771a: 694) identified Spöring and Jonathan Monkhouse as the two observers. Nor do we know the number of telescopes involved, or their appearance. In his journal entry of 2 June, Banks describes how: "Before night our observatory was in order, telescopes all set up and tried \&c. and we went to rest anxious for the events of tomorrow." (Beaglehole 1963, I: 284, my italics). This indicates that there were two or three telescopes, and the preparations mentioned by Banks strongly suggest that Gregorian reflectors rather than portable marine telescopes were involved. Nor is there any information about the time-keeper used, but this would have been either the journeyman clock or the alarum clock. Finally, we should note that although Joseph Banks accompanied the Irioa Island party to Moorea, he took no part in the transit observations (Beaglehole 1963, I: 284-285).

We know from various letters penned by Cook (e.g. Cook 1770) that all three parties successfully observed the transit, which lasted for a little over six hours, and that Fort Venus fully justified its name in that "... no Indians was allow'd to come near us that nothing might disturb the Observation." (Molyneux 1769: 559). The main focus of all three observing parties was the ingress and egress contacts, but where telescopes were furnished with micrometers, observers also were able to measure the diameter of Venus while superimposed on the Sun's disk. Cook reported from Fort Venus: “This day prov'd as favourable to our purpose as we could wish, not a Clowd [sic] was to be seen the whole day and the Air was perfectly clear, so that we had every advantage we could desire in Observing the whole of the passage of the Planet Venus over the Sun's disk: we very 
distinctly saw an Atmosphere or dusky shade round the body of the Planet which very much disturbed the times of the Contacts particularly the two internal ones [see Fig. 4]. $\mathrm{D}^{\mathrm{r}}$ Solander observed as well as $\mathrm{M}^{\mathrm{r}}$ Green and my self, and we differ'd from one another in observeing $[s i c]$ the times of the Contacts much more than could be expected. $\mathrm{M}^{\mathrm{r}}$ Green's Telescope and mine were of the same Magifying [sic] power but that of the $\mathrm{D}^{\mathrm{r}}$ was greater than ours." (Beaglehole 1968: 97-98). We know that Green \& Cook (1771: 410 ) used a magnification of $140 \times$. In the course of the transit Green and Cook also measured the diameter of Venus. They used one of the Short telescopes with the Dollond

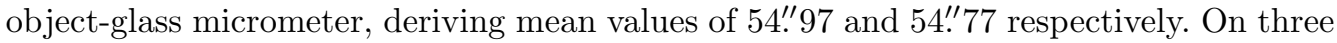
different occasions Cook also measured the planet's diameter with a telescope of 18 inches focal length (probably the Watkins reflector) and a Dollond micrometer, obtaining mean values of 56." 8,56 . $^{\prime} 8$ and 56.'02 (Green \& Cook 1771: 412-418). He also used the Short reflector and Dollond micrometer to take a series of measurements of the separation between Venus's limb and the limb of the Sun, and to measure the diameter of the Sun (Green \& Cook 1771: 413-415).

With the transit behind him Cook was now free to open the sealed orders from the Admiralty, and these revealed that this scientific venture would now become a voyage of exploration, in search of the mooted southern continent, Terra Australis Incognita. In fact this quest proved singularly unsuccessful, and after re-discovering and then circumnavigating New Zealand and charting much of the east coast of Australia, Cook made his way home to England via epidemic-ridden Batavia (present-day Jakarta) and Cape Town. In the process, seven of the thirteen individuals directly involved in the transit of Venus observations perished, while an eighth (the troublesome Patrick Saunders) deserted while the Endeavour was anchored at Batavia. Given this mortality rate, fatalists could be excused for thinking that the Tahitian transit carried a curse of Tutankhamen-like proportions!

\section{From transit to parallax}

As soon as the transit was over, all observers handed over their records to Green for safe-keeping (Cook 1771a: 692), and when the Endeavour reached Batavia he sent copies of them to the Royal Society, enclosed in a packet that Cook sent to the Admiralty via a Dutch ship (Cook 1771b: 694). The Endeavour quit Batavia on 26 December 1770 and it was only when Green died of dysentery on 29 January 1771 that Cook discovered the shocking state of the astronomical records: “... my first care was, to preserve, for the perusal of the Royal Society, all his papers that contained any Astronomical observations of what nature soever; many of which I had never seen before; and I found far from having been kept in that clear order their importance seemed to require ..." (ibid.; cf. Wales 1788: i.). Unfortunately, Green never briefed Cook on precisely which records were sent to the Royal Society, so Cook "... caused copies of all those that had any relation to the Transit of Venus, and for fear of any accident happening to us, I put them on board His Majesty's Ship Portland addressed to Mr Maskelyne ..." (Cook 1771b: 695). This occurred on 10 May 1771, when the Endeavour and Portland were anchored at Ascension Island (Beaglehole 1968: 469). Cook (1771a: 693-694) reveals that the letter to Maskelyne contained the following enclosures:

"1. Observations of equal altitudes of the un for the time; and observed altitudes or Zenith distances of the sun and stars for the latitude.

2. Observations of Jupiters Satellites for the longitude; and of the times of the contacts of the limbs of the sun and Venus observed by $\mathrm{M}^{\mathrm{r}}$ Green.

3. Lunar observations of the Moons distances from the sun and fixed stars for the 




Figure 4. Drawings by Cook and Green illustrating the transit contacts, as seen at Fort Venus (after Green \& Cook 1771: facing page 410).

longitude; and Cap $^{t}$ Cook's observations of the times of the contacts of the limbs of the sun and Venus.

4. $\mathrm{M}^{\mathrm{r}}$ Green's observations of the diameters of the Sun and Venus; nearest approach of their centers; difference of Declination, distances of their limbs in a direction parallel to the Equator; all observed with Dollond's Micrometer.

5 . Observations of the transit of Venus made at York Island [=Moorea] by $\mathrm{M}^{\mathrm{r}}$ Monkhouse and $\mathrm{M}^{\mathrm{r}}$ Sporing; and Dr Solander's observations of the two external and first internal contacts of Venus at Georges Island.

6. Observations of the transit of Venus at Morton's Island [=Taaupiri Island] by Lieu ${ }^{\mathrm{t}}$ Hicks, Clerk, Saunders, and Pickersgill." 
Cook also explains to Maskelyne why these documents were sent to him rather than the Royal Society: "If I recollect right $\mathrm{M}^{\mathrm{r}}$ Green has made some mistake in the observations he sent home, of the beginning and end of the Transit, as it was by him observed; at least I do not find the true times that he observed the different contacts faithfully entered in any of his books or papers; on the contrary I find them put down in two places, and different from each other, and neither the one nor the other are precisely the same as they were observed; the alterations that have been made will appear from the inclosed papers, and from them you will be able to judge how far it was reasonable to make such alterations, and this is the reason why I wish you to have the perusal of these papers before they are laid before the Royal Society ..." (Cook 1771a: 693).

Subsequently, Cook had yet another copy made "... of all or most of the observations relating to the Transit, that I know to be authentic, made by $\mathrm{M}^{\mathrm{r}}$ Green, my self and others ..." (Cook 1771b: 695), and on 11 July 1771, as the Endeavour reached England, he sent these and all of Green's papers to the Secretary of the Royal Society (ibid.).

Once he was safely settled in England, Cook faced the non-trivial task of trying to make sense of these confusing observations, and it is much to his credit that he subsequently was able to publish a report in the Philosophical Transactions of the Royal Society, with Green serving as a deserving posthumous co-author (Green \& Cook 1771). "Observations made, by appointment of the Royal Society, at King George's Island in the South Seas" appeared in 1771, spans 25 journal pages, and provides readers with details of the transit (including contact drawings by Cook and Green), lists of observations made for timekeeping purposes and in order to determine the latitude and longitude of Fort Venus, and includes some magnetic and tidal records. The transit itself occupies approximately half of the paper, but only details the observations made by Cook, Green and Solander notwithstanding the aforementioned problems associated with Green's contact timings. Perhaps this is why, at the bottom of the very last page of the paper, Cook acknowledges Maskelyne's assistance in preparing the final manuscript. Surprisingly, none of the contact timings made at Irioa Island or Taaupiri Island is included, and indeed the sole mention of these two observing stations is almost an aside: "Some of the other gentlemen, who were sent to observe at different places, saw at the ingress and egress the same phenomenon as we did; though much less distinct, which no doubt was owing to their telescopes being of less magnifying power ..." (Green \& Cook 1771: 411). Although at least three copies of the Irioa Island and Taaupiri Island observations were at one time or another sent to the Royal Society (one set via Maskelyne), and all of the original transit papers were also lodged there, none of these records has survived (G. Richardson, pers. comm., 2000), and searches by the author at other 'obvious' repositories such as the RGO Archives at Cambridge and the National Maritime Museum have also proved fruitless. Thus, we cannot examine the original records to determine why Cook chose not to include contact times from the ancillary observing stations. Nor can we see what observations - if any Molyneux contributed from Fort Venus, and how Green's various timings listed in the original records compare and contrast with those in the published paper.

While Cook was working on the Royal Society paper, the talented Thomas Hornsby was analysing the British transit observations with the aim of coming up with a meaningful figure for the solar parallax. After reviewing the available readings he decided to employ data provided by the British Tahitian and Hudson Bay missions, Chappe's French expedition to Baja California, Rumovsky's Russian site at Kola and Hell's Danish station at Vardö. Critical to the success of this exercise were reliable latitudes and longitudes for the different observing stations and consistent second and third contact timings, but even this selective dataset presented Hornsby with problems. For instance, the times that Cook, Green and Solander registered for these two contacts varied by as much as thirteen 
Table 1. Contact Timings at Tahiti (Local time).

\begin{tabular}{crrc}
\hline Contact & \multicolumn{1}{c}{ Cook } & Green & Solander \\
\hline 1 & $7 \mathrm{~h} 21 \mathrm{~m} \mathrm{25s}$ & 7h 21m 20s & 7h 21m 46s \\
2 & $7 \mathrm{~h} \mathrm{38m} \mathrm{55s}$ & 7h 38m 55s & 7h 39m 08s \\
3 & $13 \mathrm{~h} \mathrm{09m} \mathrm{56s}$ & $13 \mathrm{~h} \mathrm{09m} \mathrm{46s}$ & - \\
4 & $13 \mathrm{~h} \mathrm{27m} \mathrm{45s}$ & $13 \mathrm{~h} \mathrm{27m} \mathrm{57s}$ & $13 \mathrm{~h} \mathrm{27m} \mathrm{56s}$ \\
\hline
\end{tabular}

seconds, and similar discrepancies also characterized the first and fourth contacts. Table 1 lists the various contact times, and this compilation shows that Cook and Green were sometimes in accord and Solander was the 'odd man out', while at other times Green and Solander agreed and Cook's was the dissident reading. In other words there was no consistent pattern, so it was not possible to derive correction factors for the different observers.

Although we now know that such discrepancies are to be expected and that the variations documented in Tahiti were by no means excessive, at the time Cook was just a little disappointed (Beaglehole 1968: 98) - even if the reasons for them were only too obvious. In his Royal Society paper he wrote how it was “... very difficult to judge precisely of the times that the internal contacts of the body of Venus happened, by reason of the darkness of the penumbra at the Sun's limb, it being there nearly, if not quite, as dark as the planet. At this time a faint light, much weaker than the rest of the penumbra, appeared to converge towards the point of contact, but did not quite reach it ... in like manner at the egress the thread of light was not broke off or diminished at once, but gradually, with the same uncertainty: the time noted was when the thread of light was wholly broke by the penumbra." (Green \& Cook 1771: 411). What Cook was alluding to was the notorious and long-misunderstood 'black drop effect' (see Schaefer 2001; Pasachoff et al., these proceedings), but this did not prevent Hornsby (1771) from coming up with a solar parallax value of 8." 78 (cf. Howse \& Murray 1997), a figure that is remarkably similar to the 8 "! 80 obtained by Pingré and the currently-accepted value of 8 "'794148.

Had Hornsby's and Pingré's parallax values been the only ones obtained from the 1769 transit then the Earth-Sun distance would have been beyond dispute, but unfortunately Hell came up with a figure of 8 "' 70 , while Euler obtained 8."63, Lalande 8". $55-8$. "63 and Planmann 8." 43 (see Woolf 1959: 190-191). The problem was that the difference between 8.' 80 and 8." 43 equated to a difference in the astronomical unit of $\sim 6.57 \times 10^{6} \mathrm{~km}$, which was totally unacceptable. Was a value for $\mathrm{P}$ in the 'high suite' of Hornsby and Pingré correct, or in the 'low suite' represented by Euler, Lalande and Planmann; and what of Hell's intermediate figure? Hopefully, the next pair of transits, in 1874 and 1882, would resolve this issue.

In fact both nineteenth century transits came out in favour of the 'high suite' of figures, as did other non-transit means of determining P, and Newcomb's reworking of all four transit results and review of the entire system of constants between 1891 and 1895 showed

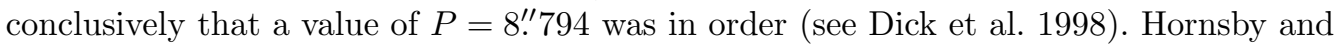
Pingré had been right all along ... and with the benefit of hindsight we must applaud the following remarks, made by Hornsby back in 1771: “. . f from the observations made in distant parts by the astronomers of different nations, and especially from those made under the patronage and direction of the [Royal] Society, the learned of the present time may congratulate themselves on obtaining as accurate a determination of the Sun's distance, as perhaps the nature of the subject will admit." (Hornsby 1771: 574). 


\section{Concluding remarks}

Lieutenant James Cook's first expedition to the South Seas was primarily undertaken as a voyage of science, and it was only after the transit of Venus was successfully observed that it became a voyage of exploration. Cook and Green were the 'official' astronomers on the Endeavour and were supplied by the Royal Society and the Royal Observatory at Greenwich with the best scientific instruments available, but Cook, Solander and some of the officers also brought along their own instruments. Three different Tahitian observing stations were established and all observers successfully recorded the transit, but there is confusion about how many active observers there were at the different stations, and the telescopes and time-keepers they used.

Moreover, when Cook came to write up the official account of the transit he only drew on observations made by himself, Green and Solander at Fort Venus, and for some reason ignored the dedicated observers based at Irioa Island and Taaupiri Island. To compound the mystery, the currently whereabouts of their original observations, and those made by Green and Solander, is unknown. Skelton (1954: 116) has noted that many of the coastal charts prepared during the voyage have disappeared, and it would seem that the transit records followed a similar path.

Most of the astronomical instruments associated with the Tahitian transit observations have also suffered a similar fate, and the current whereabouts of very few of them is known. While two Short telescopes with indisputable transit affiliations are in the Science Museum, London, there is no proof that either of these is the one that accompanied Cook to Tahiti (see Howse 1979; Orchiston 1998b). The current whereabouts of the Watkins reflector is unknown, but the telescope used by Solander at Fort Venus is probably the Heath and Wing reflector now housed in The Museum of New Zealand Te Papa Tongarewa, in Wellington (see Orchiston 1999). The situation regarding the Tahitian Bird quadrant is little better: admittedly, there are three different 12-inch Bird quadrants in the Science Museum, London, but there is no proof that any of these was on the Endeavour. The saga of the Cook voyage time-keepers is only marginally better: neither First Voyage journeyman clock nor alarum clock has survived (Howse \& Hutchinson 1969), but Howse \& Murray (1997) believe that the Shelton astronomical clock used at Fort Venus is now in the National Museum of Scotland, in Edinburgh.

While Cook's First Voyage was an outstanding success in terms of anthropology, botany, geography and zoology, and Cook acquired an instant reputation as a successful explorer, the astronomical outcome of the voyage was in dispute. Although Hornsby used the Tahitian data (amongst others) to derive a value for the solar parallax of 8.78 , which is remarkably similar to the currently-accepted figure, others came up with results that ultimately raised doubts about the validity of these transits as a means of determining the astronomical unit. Thus, Beaglehole (1968: cvi; cxliv) has made the oft-quoted claim that the Tahitian observations were a failure, but we concur with Waldersee (1969) and strongly dispute this. While he is a revered figure and is undoubtedly the world's leading Cook authority, Beaglehole was no astronomer, and did not have access all the evidence. As Sir Richard Woolley (1970: 135) has so aptly reminded us, nineteenth century astronomers using data from the 1761 and 1769 transits "... knew the distance to the Sun much better than present-day astronomers know the distance to the centre of the galaxy."

\section{Acknowledgements}

I am grateful to the following for their assistance: Ms Gudrun Richardson (The Royal Society), Peter Hingley (RAS Library), Adam Perkins (RGO Archives, Cambridge), Dr 
Stuart Ryder (Anglo-Australian Observatory) and staff at the Mitchell Library (Sydney), British Library (London), National Maritime Museum (London) and the Science Museum (London). I also wish to thank the Science Museum (London) for permission to publish Fig. 1, the Donovan Trust (Sydney) for helping fund a research trip to England, and the IAU for awarding a Travel Grant that made it possible for me to attend the Preston meeting where an earlier version of this paper was given.

\section{References}

Admiralty 1768. Letter to Lieut. James Cook, dated 25 May. Original in the Public Record Office, London (Adm 2/94). Abstract in Beaglehole, 1968: 609.

Badger, G.M. 1970. Cook the scientist. In Badger, G.M. (ed.). Captain Cook Navigator and Scientist. Canberra, Australian National University Press. Pp. 30-49.

Banks n.d., Transactions of the Royal Society relative to the sending out people to Observe the transit of Venus in 1769. Original in the National Library of Australia, Canberra. Reprinted in Beaglehole, 1968: 511-514.

Beaglehole, J.C. (ed.) 1963. The Endeavour Journal of Joseph Banks 1768-1771. Two volumes. Second Edition. Sydney, Public Library of New South Wales in association with Angus and Robertson.

Beaglehole, J.C. (ed.) 1967. The Journals of Captain James Cook On His Voyages of Discovery. III. The Voyage of the Resolution and Discovery 1776-1780. Two volumes. Cambridge, Cambridge University Press.

Beaglehole, J.C. (ed.) 1968. The Journals of Captain James Cook On His Voyages of Discovery. I. The Voyage of the Endeavour 1768-1771. Cambridge, Cambridge University Press.

Beaglehole, J.C. 1974. The Life of Captain James Cook. London, Hakluyt Society.

Betts, J. 1993. The eighteenth-century transits of Venus, the voyages of Captain James Cook and the early development of the marine chronometer. Antiquarian Horology, 21: 660-669.

Cook, J. 1767. An observation of an eclipse of the Sun at the island of New-found-land, August 5, 1766. Philosophical Transactions of the Royal Society, 57: 215-216.

Cook, J. 1768. Letter to the Admiralty Secretary, dated 27 July. Original in the Public Record Office (Adm 1/1609). Reprinted in Beaglehole, 1968: 621.

Cook, J. 1770. Letter to the Admiralty Secretary, dated 23 October. Original in the Mitchell Library. Reprinted in Beaglehole, 1968: 499-501.

Cook, J. 1771a. Letter to Nevil Maskelyne, dated 9 May. In the Royal Society Council Minutes of 11 July 1771. Reprinted in Beaglehole, 1968: 692-694.

Cook, J. 1771b. Letter to the Secretary of the Royal Society, dated 11 July. In the Royal Society Council Minutes of 25 July 1771. Reprinted in Beaglehole, 1968: 694-695.

Deptford Yard Officers 1768a. Letter to the Navy Board, dated 27 March. Original in the Public Record Office, London (Adm 106/3315). Abstract in Beaglehole, 1968: 606.

Deptford Yard Officers 1768b. Letter to the Navy Board, dated 7 October. Original in the Public Record Office, London (Adm 106/3315). Abstract in Beaglehole, 1968: 624.

Dick, S.J., Orchiston, W., \& Love, T. 1998. Simon Newcomb, William Harkness and the nineteenth century American transit of Venus expeditions. Journal for the History of Astronomy, 29: 221-255.

Douglas, J. n.d., Hints offered to the consideration of Captain Cooke, $\mathrm{M}^{\mathrm{r}}$ Bankes, Doctor Solander, and the other Gentlemen who go upon the Expedition on Board the 
Endeavour. Original in the National Library of Australia, Canberra. Reprinted in Beaglehole, 1968: 514-516.

Green, C., \& Cook, J. 1771. Observations made, by appointment of the Royal Society, at King George's Island in the South Seas. Philosophical Transactions of the Royal Society, 61: 397-421.

Hornsby, T. 1765. On the transit of Venus in 1769. Philosophical Transactions of the Royal Society, 55: 326-344.

Hornsby, T. 1771. The quantity of the Sun's parallax. Philosophical Transactions of the Royal Society, 61: 574-579.

Howse, D. 1979. The principal scientific instruments taken on Captain Cook's voyages of exploration, 1776-80. Mariner's Mirror, 65: 119-135.

Howse, D., \& Hutchinson, B. 1969. The Clocks and Watches of Captain James Cook 1769-1969. London, The Antiquarian Horological Society.

Howse, D., \& Murray, A. 1997. Lieutenant Cook and the transit of Venus, 1769. Astronomy $\&$ Geophysics, 38(4): 27-30.

Molyneux, R. 1769. Remarks in Port Royal Bay in King George the thirds Island. Original in the Public Record Office (Adm 55/39). Reprinted in Beaglehole, 1968: 551-564.

Orchiston, W. 1998a. From the South Seas to the Sun. The astronomy of Cook's voyages. In Lincoln, M. (ed.). Science and Exploration in the Pacific. European Voyages to the Southern Oceans in the 18th Century. Woodbridge, Boydell Press, in association with the National Maritime Museum. Pp. 55-72.

Orchiston, W. 1998b. Nautical Astronomy in New Zealand. The Voyages of James Cook. Wellington, Carter Observatory.

Orchiston, W. 1999. Cook, Banks and the Gregorian telescope in The Museum of New Zealand Te Papa Tongarewa. Journal of the Antique Telescope Society, 18: 4-9.

Orchiston, W. 2004. The astronomical results of Cook's voyages. In Robson, J. (ed.). Captain Cook Encyclopaedia. London, Chatham Publishing, Pp. 31-35.

Parkinson, S. 1784. A Journey of a Voyage to the South Seas, in His Majesty's Ship, The Endeavour. London, printed for Stanfield Parkinson.

Ritchie, G.S. 1978. Captain Cook's influence on hydrographic surveying. Pacific Studies, 1: 78-95.

Schaefer, B.E. 2001. The transit of Venus and the notorious Black Drop Effect. Journal for the History of Astronomy, 32: 325-336.

Skelton, R.A. 1954. Captain James Cook as a hydrographer. Mariner's Mirror, 40: 92119.

Waldersee, J. 1969. Sic transit: Cook's observations in Tahiti, 3 June 1769. Journal of the Royal Australian Historical Society, 55: 113-123.

Wales, W. 1788. Astronomical Observations, Made in the Voyages which were Undertaken by Order of His Present Majesty, for Making Discoveries in the Southern Hemisphere ... London, Elmsly.

Woolley, Sir Richard 1970. The significance of the transit of Venus. In Badger, G.M. (ed.). Captain Cook Navigator and Scientist. Canberra, Australian National University Press. Pp. 118-135.

Woolf, H. 1959. The Transits of Venus: A Study in the Organisation and Practice of Eighteenth-Century Science. Princeton, Princeton University Press.

\section{Discussion}

STEVE Dick: I guess the question is whether they got it right by accident or ...?

WAyne Orchiston: Well we don't know that; it's easy to be wise after the event. 
JACQUELINE MitTON: Is it known whether observations were made by projection or otherwise? I was looking quite recently at a book which suggested there was a phrase like "all eyes to the telescope". You just mentioned the possible use of filters with a sextant or quadrant, but as far as I am aware no safe filters had been devised at that time. So what were they up to? Were they risking their eyesight, or did they project, or $\ldots$ ?

Wayne Orchiston: That's an excellent question. It's one that has occurred to me, too, Jacqueline, and I've not been able to find any documentation. This is one of the problems with going through this literature. There are descriptions of what was done, but not the actual precise detail of the observing techniques. Given that sextants were used for solar observations, obviously there were filters that were suitable. I had presumed that they would have adapted those for the Gregorian telescopes, and one would assume that they would have made plenty of test observations with these sorts of instruments here in Britain before they left on the expedition. But I would really like to get some documentation of the evidence for that, so I don't know. Thank you for raising it though.

Nick Kollerstrom: You described the expedition with the distinguished astronomers on board. Would you confirm that they used the lunar method for longitude in their voyage. This is one of the few main journeys when it was the main method of finding longitude, and it continued to be used as a backup after the clocks - chronometers came in. Was this a very difficult thing to do?

Wayne Orchiston: For the first voyage, of course, there were no chronometers on the Endeavour. They only came with the second and third voyages, so the lunar method of determining longitude was the standard practice that was used for navigation on the first voyage. Part of the training that Green was required to give any of the lower officers - and particularly able bodied seamen who wanted to move up through the hierarchies (as Cook himself had done) - was to teach them the basic principles of lunars, so they were learning nautical astronomy as well as transit astronomy during the voyage. And you will also recall, of course, the longitude prize - there was a prize of up to $£ 30000$, if I remember rightly - to provide accurate chronometers that could be used on round the world voyages. One of those who was on the committee to make decisions about the allocation of their funding was Maskelyne, the Astronomer Royal, who, of course, was pushing the lunars method and hoping that he would get that prize for the Royal Observatory. So there were actually vested interests - very interesting politics - to look at the first voyage versus the second and third, in relation to navigation in terms of lunars and the different chronometers.

DAVID SELLERS: Just a quick point on the use of filters: there is a paper by Maskelyne I think it's in relation to the 1769 transit - where he said that his preference is to use smoked glass, as opposed to red glass, which he doesn't like. I'm not sure what the red glass consisted of.

Wayne Orchiston: Thank you, David, I appreciate that.

Allan Chapman: Back on the filter subject: in the Museum of the History of Science, for instance, where there are several Short telescopes surviving with their cases and all of their micrometers, and everything, they all used to carry standard filters as normal, just to screw them in - often in deep red and often deep green. These, of course, were not for the transit as such, but were just for solar observing. I think we are now very 
much more concerned about eyesight than they were. William Lassell - in 1851 when he went to observe the eclipse of the Sun at Norway with a 33/4-inch Merz refractor describes seeing the Sun come out of eclipse, and he describes how it started shattering his eye-piece filters, and he kept several of them in his waistcoat pocket, and every time a filter shattered he'd screw a new one in; that's how they operated in those days.

Wayne Orchiston: Yes, thank you. Certainly there's a lot of evidence that there were filters issued with most of these Short telescopes, and the comment you make, Allan, about the later times is well documented; a lot of observers with the 1874 transit had problems with filters.

MARILYN HEAD: I have been always intrigued by the secret instructions given to Cook, especially as they effected us [New Zealanders] ... and you say that the expedition was primarily a scientific one, not a political one?

Wayne Orchiston: Yes, various people have put forward that latter view, but in the public eyes when this voyage was announced, when it was publicised, and also in the eyes of the Royal Society, of Royal Observatory, and certainly of the Navy, this was a scientific expedition. It was only after the science had been achieved, if in fact it was possible, to address a second issue. Of course, with the benefit of hindsight, and also looking at the raison d'être of the second and the third voyages, it becomes much easier to interpret the second part of that first voyage as a voyage of discovery and exploration - which indeed it was - but that was not the primary function, and that was not the reason that the funding was allocated by King George III.

WALTER Brisken: We have been talking mostly about the scale of the solar system, but when did we become aware of the eccentricity of the Earth's orbit around the Sun and how does that relate to the early measurements of AU?

WAyne Orchiston: I'm not really the person to answer that. There are a whole range of people in this audience who would be much more competent to. I'm sure Alan Chapman or Dave Hughes ...

Allan Chapman: I missed the exact question, I'm sorry.

WALTER BRISKEN : What effect does the eccentricity of the Earth's orbit have on these measurements?

WAYNe Orchiston: ... and who was the first one to detect that?

Allan Chapman: Who was ...? I'm afraid I don't know that.

Steve Dick: Myles do you have anything to add?

WAYNe ORChiston: ... but who was the first person to actually publish on the eccentricity? Do you know?

MYles StAndish: ... Greek astronomers, collectively.

STEve Dick: Yes, it's an interesting question: what's the magnitude of the effect of the eccentricity. Maybe we'll mull that over overnight. 